\title{
GCU
}

Glasgow Caledonian

University

University for the Common Good

\section{Principles for responsible management education in 2068}

Huntley Henderson, Lionel ; Wersun, Alec; Wilson, John ; Yeung, Shirley Mo-ching; Zhang, Kejing

Published in:

FUTURES: The Journal of Policy, Planning and Future Studies

DOI:

10.1016/j.futures.2019.05.005

Publication date:

2019

Document Version

Author accepted manuscript

Link to publication in ResearchOnline

Citation for published version (Harvard):

Huntley Henderson, L, Wersun, A, Wilson, J, Yeung, SM \& Zhang, K 2019, 'Principles for responsible

management education in 2068', FUTURES: The Journal of Policy, Planning and Future Studies, vol. 111, pp. 81-89. https://doi.org/10.1016/j.futures.2019.05.005

\section{General rights}

Copyright and moral rights for the publications made accessible in the public portal are retained by the authors and/or other copyright owners and it is a condition of accessing publications that users recognise and abide by the legal requirements associated with these rights.

Take down policy

If you believe that this document breaches copyright please view our takedown policy at https://edshare.gcu.ac.uk/id/eprint/5179 for details of how to contact us. 


\title{
Principles for Responsible Management Education in 2068
}

\begin{abstract}
The authors explore the potential relevance of the United Nations initiative Principles for Responsible Management Education (PRME) in 50 years' time, including whether, and how, the six Principles on which it is based will change in any way.

More than 10 years' after the launch of PRME, the need to address sustainability in management education is perhaps becoming even more acute, in part due to indirect and contextual issues, including those relating to the environment and geopolitics, and in part due to more direct factors, such as the trends in artificial intelligence. In this context, the authors consider whether PRME might still exist in 2068 and, if so, what it might look like. The research is based on semi-structured discussions, based on the seven questions approach, involving the authors and participants who were senior managers, academics and students based in PRME signatory higher education institutions in China and/or had academic expertise in the area of corporate social responsibility (CSR). The principal results are the imagined institutional, educational, and occupational changes that may have an impact on the future of PRME. The main conclusions are an ongoing investigation of the 'wicked problems' as identified in the findings.
\end{abstract}

Keywords: Futures Studies; Strategic Conversations; PRME; Management Education; Sustainability; Corporate Social Responsibility 


\section{Principles for Responsible Management Education in 2068}

\section{Response to Reviewers' Comments}

\begin{tabular}{|c|c|}
\hline Reviewer 1 Comment & \\
\hline $\begin{array}{l}\text { The focus on China is interesting and welcome given that } \\
\text { participation in PRME is relatively rare given the size of the sector } \\
\text { there but where potential is almost unlimited. The methodology } \\
\text { section is somewhat brief however and would benefit from a fuller } \\
\text { explanation of the analysis method - what method of thematic coding } \\
\text { was used? }\end{array}$ & More detail has been supplied \\
\hline Page 8 - final paragraph - 'humanities' should be 'Humanity's' & Corrected \\
\hline $\begin{array}{l}\text { Some interesting discussion points - be interesting to repeat the } \\
\text { process across different regions to see if similar thoughts are offered. }\end{array}$ & $\begin{array}{l}\text { The point of further research } \\
\text { across regions has been } \\
\text { added (See Conclusion) }\end{array}$ \\
\hline Reviewer 2 Comment & Response \\
\hline $\begin{array}{l}\text { The paper presents an interesting premise in looking forward } 50 \\
\text { years and the relevance and contribution to management of PRME in } \\
\text { addressing the worlds most pressing issues (identified by the authors } \\
\text { as 'wicked problems'. However, we are now in } 2019 \text { (not 2018) so the } \\
2068 \text { timeframe may need to be looked at (although it is recognised } \\
\text { that the research was probably conducted in 2018). The context of } \\
\text { China as the source for the participants is also interesting and some } \\
\text { justification is provided for this choice but see comments re } \\
\text { participants below. }\end{array}$ & $\begin{array}{l}\text { Timeframe remains as } 2068 \\
\text { consistent with the } 50 \text { years' } \\
\text { timeframe of the Special Issue }\end{array}$ \\
\hline $\begin{array}{l}\text { At the outset, there are some corrections to make in what appears to } \\
\text { be a lack of understanding about PRME and these are fundamental } \\
\text { to the questions being asked. Firstly, the organisation is the } \\
\text { Principles FOR Responsible Management Education and } \\
\text { not OF. This is a distinct difference in being a champion for } \\
\text { something rather than claiming to have ownership of the field. In this } \\
\text { regard PRME works with many other organisations and agencies in } \\
\text { this space. }\end{array}$ & $\begin{array}{l}\text { 'Principles for' now corrected } \\
\text { throughout }\end{array}$ \\
\hline $\begin{array}{l}\text { Secondly, much is made of the need for PRME to address 'wicked } \\
\text { problems' of sustainability including climate change but there } \\
\text { is limited discussion of the Sustainable Development Goals (SDGs). } \\
\text { Yet PRME was involved in the consultation process that led to the } \\
\text { launch and agreement by all member states of the Sustainable } \\
\text { Development Goals (SDGs) that came into force in January } \\
\text { 2016. The SDGs now form the joint framing for PRME, in that the } \\
\text { SDGs are the agenda (in line with Agenda 2030) for content of } \\
\text { initiatives (the 'what' for areas of action) and the Principles are 'the } \\
\text { how' (for implementing strategies, plans and practices). Thus all } \\
\text { signatories are now required to use the joint framings in their work } \\
\text { and report on both in their SIPS (sharing information on progress). }\end{array}$ & $\begin{array}{l}\text { The SDGs had been referred } \\
\text { to in the original but it is } \\
\text { recognised that these needed } \\
\text { to be enhanced and there are } \\
\text { now more references to SDGs } \\
\text { in the text and a specific } \\
\text { inclusion in the list of } \\
\text { References to the UN website }\end{array}$ \\
\hline $\begin{array}{l}\text { There are many places when 'author' is used presumably as a place } \\
\text { holder until the reference is found but this is unacceptable in } \\
\text { submitting an academic paper. Similarly, there are statements made } \\
\text { with no reference at all. }\end{array}$ & $\begin{array}{l}\text { 'Author' has been deleted } \\
\text { throughout and a complete list } \\
\text { of references is included. The } \\
\text { changes as requested by } \\
\text { reviewer } 2 \text { have been made } \\
\text { but please note this does } \\
\text { appear to conflict with the } \\
\text { Guide for Authors, as found on }\end{array}$ \\
\hline
\end{tabular}




\begin{tabular}{|c|c|}
\hline & $\begin{array}{l}\text { the Futures journal website } \\
\text { (see Double-blind review and } \\
\text { Review Policy). The non- } \\
\text { inclusion, in the original, of any } \\
\text { identifying features (e.g. } \\
\text { author's name and } \\
\text { publications) was to be } \\
\text { consistent with the original } \\
\text { Guide for Authors. However, } \\
\text { this has now been reversed } \\
\text { and details added. }\end{array}$ \\
\hline $\begin{array}{l}\text { Overall, the references are very limited with regard to ESD education } \\
\text { and in relation to PRME. There are many articles written on ESD } \\
\text { education over a long period and multiple papers written on PRME in } \\
\text { recent years including articles from (but not exclusively) the PRME } \\
\text { 10th Anniversary Special of the International Journal of Management } \\
\text { Education that includes } 26 \text { articles with a retrospective of PRME over } \\
\text { its first decade and a look forward to the era of the SDGs. }\end{array}$ & $\begin{array}{l}\text { Some of the articles in the } 10^{\text {th }} \\
\text { year special edition had been } \\
\text { referenced in the original (e.g. } \\
\text { Wersun, A) but have now been } \\
\text { supplemented (e.g. Parkes et } \\
\text { al) }\end{array}$ \\
\hline $\begin{array}{l}\text { Students are referred to as the 'forgotten voices' of youth and the } \\
\text { future yet information about who they are or what the group } \\
\text { represents is missing. There are also multiple PRME related } \\
\text { initiatives with, for and on behalf of students - see PRiME Time that is } \\
\text { not mentioned or referenced. }\end{array}$ & $\begin{array}{l}\text { Reference now made, in the } \\
\text { text and list of References, to } \\
\text { the biennial survey of Haski- } \\
\text { Levanthal * Manfield and } \\
\text { reference also made to } \\
\text { PRiMEtime. } \\
\text { The contribution of the student } \\
\text { sample has been justified (see } \\
\text { 1.4.2 Participant Invitation) } \\
\end{array}$ \\
\hline $\begin{array}{l}\text { Methodologically, the paper is problematic because of the design of } \\
\text { the study and the lack of information provided. The participants are } \\
\text { posited, to some extent, as 'quasi experts' on PRME. Using focus } \\
\text { groups and interviews is legitimate but in this paper, there are serious } \\
\text { flaws in some of the factual information and literature needed to } \\
\text { seriously critique the subject matter. Testing out the responses of the } \\
\text { participants against this and/or additional interviews with other PRME } \\
\text { respondents more familiar with PRME could be a way forward. }\end{array}$ & $\begin{array}{l}\text { We were not sure what the } \\
\text { flaws were with regards to } \\
\text { 'factual information' but it has } \\
\text { now been stressed in the } \\
\text { article that the views } \\
\text { expressed by the participants } \\
\text { are not presented as } \\
\text { necessarily 'authoritative' or in } \\
\text { any sense ones that must be } \\
\text { accepted as 'factual'. On the } \\
\text { contrary, the exploratory } \\
\text { nature of the study is stressed } \\
\text { and the need for further } \\
\text { research, to obtain the } \\
\text { opinions of other participants, } \\
\text { particularly in China, is stated. } \\
\text { The point of further research } \\
\text { across regions with other } \\
\text { PRME respondents has been } \\
\text { added (See Conclusion) }\end{array}$ \\
\hline
\end{tabular}


1. Is it wise to institutionalise responsible management, and who defines what is 'responsible'?

2. Should the principles which define the Principles for Responsible Management Education be modified such that they explicitly map against, and thereby help resolve, emerging 'wicked problems'?

3. Can the Principles for Responsible Management Education derive a legitimacy independent of the United Nations, given possible uncertainty for the future or even existence of the UN itself by 2068 ?

4. Should the governance and configuration of the Principles for Responsible Management Education be decentralised, facilitating evaluation of the local impact of, and responses to, global 'wicked' issues?

5. Can, or should, management education cease to be a discrete discipline but, rather, be imagined as one which fully supports, and is integrated with, other disciplines? 


\section{Principles for Responsible Management Education in 2068}

Corresponding Author: Dr. Lionel Huntley Henderson The Sino-British College, USST 1195 Fuxing Zhong Road, Shanghai, 30001. (lee.henderson@sbc.usst.edu.cn)

Dr. Alec Wersun Glasgow Caledonian University Cowcaddens Road, Glasgow G40BA. (a.wersun@gcu.ac.uk)

Professor John Wilson Donghua University 1882 West Yan-An Road, Shanghai 200051. (johnwilson@dhu.edu.cn)

Dr. Shirley Mo-ching Yeung, Head of Business School, Gratia Christian College 5 Wai Chi Street, Shek Kip Mei, Kowloon, Hong Kong. (shirleyyeung@gratia.edu.hk)

Professor Kejing Zhang, Vice-Dean Glorious Sun School of Business and Management, Donghua University 1882 West Yan-An Road, Shanghai 200051. (zhangkj@dhu.edu.cn)

This research did not receive any specific grant from funding agencies in the public, commercial, or not-for-profit sectors.

Declarations of interest: none 


\section{Principles for Responsible Management Education in 2068}

Corresponding Author: Dr. Lionel Huntley Henderson The Sino-British College, USST 1195 Fuxing Zhong Road, Shanghai, 30001. (lee.henderson@sbc.usst.edu.cn)

Dr. Alec Wersun Glasgow Caledonian University Cowcaddens Road, Glasgow G40BA. (a.wersun@gcu.ac.uk)

Professor John Wilson Donghua University 1882 West Yan-An Road, Shanghai 200051. (johnwilson@dhu.edu.cn)

Dr. Shirley Mo-ching Yeung, Head of Business School, Gratia Christian College 5 Wai Chi Street, Shek Kip Mei, Kowloon, Hong Kong. (shirleyyeung@gratia.edu.hk)

Professor Kejing Zhang, Vice-Dean Glorious Sun School of Business and Management, Donghua University 1882 West Yan-An Road, Shanghai 200051. (zhangkj@dhu.edu.cn)

This research did not receive any specific grant from funding agencies in the public, commercial, or not-for-profit sectors.

Declarations of interest: none 


\title{
Principles for Responsible Management Education in 2068
}

\begin{abstract}
The authors explore the potential relevance of the United Nations initiative Principles for Responsible Management Education (PRME) in 50 years' time, including whether, and how, the six Principles on which it is based will change in any way.

More than 10 years' after the launch of PRME, the need to address sustainability in management education is perhaps becoming even more acute, in part due to indirect and contextual issues, including those relating to the environment and geopolitics, and in part due to more direct factors, such as the trends in artificial intelligence. In this context, the authors consider whether PRME might still exist in 2068 and, if so, what it might look like. The research is based on semistructured discussions, based on the seven questions approach, involving the authors and participants who were senior managers, academics and students based in PRME signatory higher education institutions in China and/or had academic expertise in the area of corporate social responsibility (CSR). The principal results are the imagined institutional, educational, and occupational changes that may have an impact on the future of PRME. The main conclusions are an ongoing investigation of the 'wicked problems' as identified in the findings.
\end{abstract}

Keywords: Futures Studies; Strategic Conversations; PRME; Management Education; Sustainability; Corporate Social Responsibility 


\section{Principles for Responsible Management Education in 2068}

\subsection{Introduction}

Over the past decade, business schools have been responding to the needs to integrate sustainability and corporate social responsibility (CSR) in their teaching, research and institutional practices, in part to meet the requirements of accreditation bodies that increasingly emphasise the significance of and their commitment to sustainability and CSR. However, the challenge of addressing sustainability is becoming more complex given global trends, including the geopolitics of a possible new world order, the environmental impact of global warming and rapid developments in technology, for instance in artificial intelligence (AI). These contextual elements suggest great changes for the habitation, social governance and economic livelihood of humans and threaten to make existing norms obsolete. The anticipation of such change is the rationale for imagining the United Nations (UN) initiative Principles for Responsible Management Education (PRME) in 2068 in an effort to explore the potential nature of responsible and sustainable management education in fifty years' time.

Current research has not yet addressed sustainability from a Futures studies perspective, a gap which allows this paper to make a unique contribution to the literature and one that might be particularly useful by being based on the perspectives of participants based in China. However, it should be noted that the research is exploratory and the views reported, irrespective of how wellinformed, are not presented as necessarily valid or prescient and the extent to which they reflect wider views in China will be investigated by further research.

The paper includes the background to PRME and sustainability in education, the methodological steps taken, including an environmental scanning exercise, to conduct and analyse the conversations and consider the implications for PRME, management education and Futures studies.

\subsection{PRME and Sustainability in Education}

PRME began in 2007 as a response by business schools worldwide to embed sustainability within the management education curriculum, as requested by the UN Global Compact. As at March 2019 there are over 700 institutions worldwide that are PRME signatories (see: http://www.unprme.org/index.php). The PRME model has six Principles that encompass the values needed for addressing sustainability in management education (Table 1). Specifically, from 
2015 and the replacement of the UN Millennium Development Goals by the seventeen Sustainable Development Goals (SDGs) (see UN Website 2018), to be achieved by 2030, the Principles are intended to support management educators in relation to their contribution to the SDGs (for a summary of PRME's first decade and observations on the next decade see Parkes, Buono \& Howaidy 2017). The relevance of and potential change in the Principles by 2068, in context with the forces of change as found in the environmental scanning exercise, were the focus of this Futures study.

Table 1

\begin{tabular}{|l|l|}
\hline Purpose & $\begin{array}{l}\text { We will develop the capabilities of students to be future generators of sustainable } \\
\text { value for business and society at large and to work for an inclusive and sustainable } \\
\text { global economy. }\end{array}$ \\
\hline Values & $\begin{array}{l}\text { We will incorporate into our academic activities, curricula, and organisational } \\
\text { practices the values of global social responsibility as portrayed in international } \\
\text { initiatives such as the United Nations Global Compact. }\end{array}$ \\
\hline Method & $\begin{array}{l}\text { We will create educational frameworks, materials, processes and environments } \\
\text { that enable effective learning experiences for responsible leadership. }\end{array}$ \\
\hline Partnership & $\begin{array}{l}\text { We will engage in conceptual and empirical research that advances our } \\
\text { understanding about the role, dynamics, and impact of corporations in the creation } \\
\text { of sustainable social, environmental and economic value. }\end{array}$ \\
$\begin{array}{l}\text { We will interact with managers of business corporations to extend our knowledge } \\
\text { explore jointly effective approaches to meeting these challenges. }\end{array}$ \\
\hline Dialogue & $\begin{array}{l}\text { We will facilitate and support dialog and debate among educators, students, } \\
\text { business, government, consumers, media, civil society organisations and other } \\
\text { interested groups and stakeholders on critical issues related to global social } \\
\text { responsibility and sustainability. }\end{array}$ \\
\hline
\end{tabular}

Note: Six Principles of PRME (PRME, 2018a)

The inclusion of sustainability in higher education programmes has been a subject of considerable academic discussion since PRME originated in 2007 and many questions remain unresolved relating, for instance, to feasibility, implementation and application. In 2011, Djordevic and Cotton (2011) emphasised the importance of education for sustainability development (ESD) in all institutional, community and cultural aspects of higher education. This view was reflected two years later in 2013 by the requirements of the American business school accrediting body, the Association to Advance Collegiate Schools of Business (AACSB), to embed sustainability in all business school curricula (Nicholls et al. 2013). The same year, Ryan and Tilbury (2013) suggested 
future changes in the higher education system properly to integrate ESD to achieve effective results that reflect the ethos of the sustainability movement. Their research concluded with a recommendation to comprehend and re-evaluate the future purpose of education. This continues to be debated and, in part, is an objective of the discussions concerning PRME 2068. Specifically, Ryan and Tilbury (2013) suggested that a more fundamental review is needed in relation to teaching and learning activities in order to position ESD in such a way as to transfer sustainabilitybased skills to learners. They also suggested the need to allow learners to experience sustainable development initiatives, not only to address ESD but to develop critical thinking, creativity and to engage learners in bold discussions related to sustainability solutions. The value of such an approach was also clear from the outcomes of the student survey conducted by Haski-Levanthal \& Manefield (2018).

At present, educators still face the challenge of finding the most appropriate method of embedding sustainability into the management curriculum and to do so in a way that aligns with the practices of their corporate stakeholders. Yeung (2014) for instance, highlighted that responsible corporations need to adopt Cajazeira's (2008) seven dimensions of the CSR guidelines of ISO 26000 in their operations i.e. labour practices, consumer issues, fair operating practices, human rights, organisational governance, community involvement and the environment. Yeung's (2014) reference to Cajazereira's seven dimensions of CSR suggests that the discussion about the merits of complying with ISO 26000 is ongoing and a gap still exists in relation to sustainability standards not being fully implemented. Recently, as PRME celebrated a decade of institutional existence, Wersun (2017) outlined the challenges of overcoming the barriers to implementing PRME initiatives. The work of Yeung (2014) and Wersun (2017) suggests a practitioner-scholar dilemma for PRME signatory institutes and a need for refinement.

A possible solution to learners of a sustainability curriculum is suggested by Yeung (Unpublished results) who found that wisdom related to PRME initiatives can be generated from encountering difficulties and struggles with the learning processes of developing willpower and calmness. Yeung (Unpublished results) suggests the work of Mootee's (2013) "design thinking” to play a key role in wisdom development in sustainability education. Wisdom related to the future of PRME is absent from the Futures and sustainability literature and prompted the decision to conduct 'PRME 2068' in response to the Futures journal Call Wise N.o. 


\subsection{Environmental Scan}

At the outset of many Foresight exercises, an environmental scanning exercise is undertaken to gather information to help develop conversations and decision-making in a context of high uncertainty (Stewart \& Green, 2004). To identify potential forces of change relating to 2068, desktop research was undertaken and this was supplemented by a pilot conversation involving a former CEO of a publishing company that specialised in sustainability-related academic journals and textbooks and who is very much involved in the PRME network. This person's experience in relation to academic journals meant informed views could be expressed on issues that were the subject of journal articles and discussions within own networks. In addition to contributing to the environmental scanning exercise, the pilot was also intended to test the appropriateness of the questions to be used in the research discussions, specifically their clarity and usefulness in framing a futures-related discussion.

The pilot conversation was based on five futures-related questions (see 2.1 Results and Discussion). The wording, number and sequence of the questions had been agreed by the authors following an iterative process, noting that each question is not entirely unrelated from the others but reflects a degree of overlap. None of the elements was changed following the pilot; it was concluded that they were effective in framing the conversation.

Certain themes emerged from the pilot that were suggested to be of particular importance for the future, for management education and as forces likely to influence the PRME discourse towards 2068, viz. global warming, AI and a new world order. These themes are also supported by the desktop research (see for instance Chui et al., 2017; IPCC, 2018; Mueller et al. 2014).

Given the failure of nations worldwide adequately to address these, and other, key issues and given the importance of business and management in terms of overall student numbers and its international appeal, it may be said that there is a particular onus on business schools and associated bodies to reflect even more on the approaches they adopt genuinely to address these issues and on the role of PRME in doing so.

\subsection{Methodology}

In the context of the above environmental scan and building on the outcomes of the pilot discussion, a series of discussions was held to explore the future of PRME. The methodological 
steps, following the pilot discussion, were participant sample, participant invitation and conversations. Each is now considered.

\subsubsection{Participant Sample}

Excluding the authors, the participants were all based in China and came from PRME signatory institutions and/or had academic expertise in the area of CSR. China was the focus for three reasons. First, there is clear and rising global significance of Chinese HEIs, reflected in and in part driven by their enhanced research output (Bothwell, 2018; Nicholls et al. 2013). Second, despite the expansion and development of China's higher education system that has occurred over the past two decades, only 19 HEIs are PRME signatories (PRME, 2018b) as at the time of writing (March 2019). It may be expected that an increasing number of HEIs become involved in future PRME activities, particularly with the continued investment in national educational reform in China and the pursuit of accreditation and 'world class' status. Third, the recent trend towards a degree of disengagement by the United States of America on issues related to sustainability has gifted China an opportunity to lead global discussion and action. In short, China's development not only will have a key influence on global issues but could also be particularly significant for the future of PRME. This would be the case even if the incidence of PRME signatories in China does not increase as students and faculty in all other countries need to be aware of the importance of China for the issues the world must address and to consider the role of PRME in this regard.

\subsubsection{Participant Invitation}

A list of individuals leading the PRME Sharing Information on Progress (SIPs) reports for HEIs in China was compiled and was supplemented by experts in the area of CSR. The list also included youth (the 'forgotten voices') represented by international students from one of China's most recent (July 2018) PRME signatory institutes, i.e. Donghua University. The inclusion of students was considered to be of particular importance given their potential roles in the future as practitioners and/or educators. In addition, as international students who had decided to study in China, reinforcing their experience of studying in a number of countries other than their home country, they were able to provide a particular perspective and which enhances the invaluable insights of students included in published surveys, e.g. Haski-Levanthal \& Manefield (2018), and the information on student-related activities as captured by, for instance, resources such as the PRiMEtime website (2018). 
The 'forgotten voices' included here are unique to published PRME research for two reasons. First, the students within the sample are exclusively international undergraduate students at a public Chinese university. To date, no previous PRME research has included such a sample. HaskiLeventhal's (2013) study included MBA students at Chinese HEIs but not undergraduate students and no study since has included students based in China, whether international or domestic. In addition, subsequent surveys (Haski-Levanthal \& Concato, 2016; Haski-Levanthal \& Manefield, 2018), although extremely useful, showed a decline in participation of Chinese nationals and HEIs and this suggests a need for alternative avenues, such as the one used in this Futures study, to engage Chinese-based students in PRME research and it is considered very useful to obtain the perspectives such international students can offer. Second, in terms of the context, student feedback was obtained at a time of China's trade war with America and China's subsequent reaction to promote international trade, as demonstrated by the inaugural China International Import Expo held in November 2018. The combination of the participant sample and context made the views of the 'forgotten voices' fresh, provocative and relevant to PRME research.

All potential participants received an email outlining the rationale and purpose of the research, the questions on which the conversation would be based and a reminder as to the PRME six Principles.

\subsubsection{Conversations}

The conversations were based on five open-ended questions (see 2.1 Results and Discussion) and which, in turn, were based on three questions (the best world, the worst world and the clairvoyant question) from the seven-questions approach (Amara \& Lapinski, 1983) which are suggested by Ratcliffe (2002) to be sufficient to trigger a good discussion.

The research employed three main methodological steps in conducting the conversations, two of which were particular to Ratcliffe's (2002) advice for facilitating strategic conversations i.e. first, use of an interlocutor to help ensure the participants' comfort and capture the richest quality of conversations and, second, identification of signposts that indicate a change in direction from one prospective future to another. A third step, separate to Ratcliffe's (2002) advice, was the employment of the researcher as the main data collection instrument (Guba \& Lincoln, 1981; Janesick, 2001; 2003; Patton, 2002; Piantanida \& Garman, 1999; Shindler \& Case, 1996). The authors, with an eclectic background in a variety of academic fields, found it particularly useful to 
use Sardar's (2010) four rules of Futures studies as an analytical checklist while conducting the research.

A total of 7 conversations involving 27 participants were conducted by one of three methods, i.e. Zoom conferencing, Wechat video call or face-to-face. Each conversation was recorded, either by Zoom software and/or pen and notepad. The notes recorded by both the interlocutor and the reporter were compared, merged, and confirmed with the participants to generate official versions of the conversations. The participants' responses were thematically coded based on their institution and participant identity, both of which were anonymous. The thematic coding method of pawing, or more specifically referred to as the ocular scan method by Bernard (2000), was used. The participants' transcripts were read more than twice, as suggested by Bogdan and Biklen (1982), to get a better feeling for the conversations. Following, phrases were highlighted, that when jointly matched by colour made "some as yet inchoate sense" (Sandelowski, 1995, p. 373). The coded texts were read again and the researchers attempted to capture the nuance of each theme with an accompanying theme title The researchers purposely avoided the use of any computer software for coding the themes and relied on their instincts, followed hunches and used their intuition, which was considered a superior driving mechanism to form the themes (Dey, 1993). A theme was required to have at least two sections of text that were highlighted with the same colour. This was also representative of consensus, a quality for some Futures studies researcher methods such as The Delphi Technique, to be integrated (Rowe \& Wright, 1999; Rowe et al., 1991). The responses to the questions are now considered.

\subsection{Results and Discussion}

The discussions produced complex and intriguing results. The term 'wicked problems', initially coined by Churchman (1967), and is the basis of Sardar's (2010) first law of Futures Studies, reflects issues that are derived from uncertainty, complexity and interdependencies. Examples of 'wicked problems' found in the discussions include: the relevance of PRME in its current form as a driver of sustainability given that Humanity's very existence in 2068 may be considered to be uncertain; the need for a broader involvement of institutions (beyond corporations) involved in the focus of PRME, pending the existence of the UN and globalisation in 2068; the need to address management and governance issues within PRME. The findings are presented on the basis of the 
questions asked and, in addition, confirm the research with Sardar's (2010) other laws of Futures studies. Note that there is no significance to the order in which the themes are listed below.

\section{Table 2}

\begin{tabular}{|l|ll|}
\hline \multicolumn{2}{|c|}{ Question 1 } & \\
\hline Looking ahead to 2068, what & - Geopolitical issues \\
issues do you feel are likely to & - Poverty / Human existence \\
emerge and/or become more & - Levels of inequality and equity \\
pronounced for management & - AI \\
education? & - Management arrangements \\
& - Curriculum \\
& - Policies/Regulations \\
\hline
\end{tabular}

Note: The established themes from Question 1

There was a view that the world of 2068 may be characterised by fundamental change in the geopolitical context, with countries potentially acting in a more isolationist way and in turn having implications for management arrangements and education:

\section{Discussant 1}

I think the geopolitical context is going to become even more important. We're seeing a shift in power, from Europe and America to Asia, and I think this will be critical for management education.

\section{$\underline{\text { Discussant } 8}$}

There are likely to be more political issues, more information censorship and less globalisation. The current trade war between the US and China may take many years for its effects to be resolved and may be an indicator of future disputes.

The potential geopolitical shift would also have implications for countries' ability to deal with associated issues, including climate change and the knock-on effects in terms of 'natural' disasters. This in turn raised perhaps the most fundamental of all questions i.e. whether humans, and other species, would even still exist in 2068. Serious concern was also raised at possible levels of inequality, gender inequality, absolute poverty and equity in respect of educational access and the implications of this for, and perhaps the obligations of, management education and educators: 


\section{Discussant 4}

[We] also need to consider socio-economic class. In 50 years, the extent to which those from advantaged backgrounds understand the life of someone from a disadvantaged background.... may be even more of a problem. How can management education help the disadvantaged?

Despite the UN SDGs, which are meant to be achieved by 2030, there was a consensual pessimism about the likely future landscape of 2068, reinforced by the pace of technological change, particularly the disruptive impact of AI and probable consequences for levels of unemployment, all of which will have implications for management education:

\section{Discussant 1}

We're also seeing developments in technology, breakthrough innovation in spheres including energy, artificial intelligence, and these raise a lot of issues for management education in terms of risk, responsibility, ownership of data, access to data....and all this means we'll be dealing with an unrecognisably different world in 2068 ....

Part of the 'different world' will be reflected in the management arrangements of businesses:

\section{Discussant 7}

Companies will need to change the way they are managed, particularly the way they manage their teams, as they will need to change their operations to focus more on being sustainable. This needs to be reflected in management education.

There was, however, some doubt, given the potential 2068 context, as to whether business schools, the way they are themselves configured and the curriculum that is taught, will be fit-for-purpose:

\section{$\underline{\text { Discussant } 3}$}

Innovative companies are driving big change in the market. A number may be very small but they generate huge revenues. Some can go from start-up to IPO in two years. These 'unicorn', dujiaoshou, companies can grow fast, have unique technology and be an innovative business.....So, we have to re-shape management education.....Traditional business schools are good at creating leaders for big business, for mature and structured 
markets and organisations, but today we have unicorns and we need managers who can respond to this speed of change.

Discussant 3 illustrated the above view by what was considered to be a model to emulate, that of Steinbeis University Berlin, and linked this to the need to change the nature and curriculum of management education such that it should not be seen as a discrete subject but integrated with other disciplines and taught as an applied subject in the way that languages should be:

Discussant 3

Students in China can spend 15 years studying English but still cannot open their mouths. Why? It's because the teaching has been badly developed....Similarly, a key issue for management education is the same as language. It should be about application. Only by addressing this can management education be improved and be accessible to everyone.

It was also recognised, however, that policies and regulations, particularly in China, need to be respected and considered when a curriculum is being evaluated.

An even more fundamental view was expressed in that, particularly given the uncertainty of the future, students should be given greater guidance, more help, to think about and achieve their life goals:

\section{Discussant 6}

I think there is a more fundamental issue than the nature of management education which is that students don't set their own life targets....So, in university, the knowledge-based education should be extended to help them think about their life aim.

\section{Table 3}

\begin{tabular}{|l|ll|}
\hline \multicolumn{1}{|c|}{ Question 2 } & \multicolumn{1}{c|}{ Themes } \\
\hline Taking into account any issues & $\bullet$ Redefined and emphasized \\
identified (in question 1), to what & $\bullet$ Institutional emphasis \\
extent do you feel the Six Principles are & & \\
'future proof' or will require to be re- \\
defined and/or modified?
\end{tabular}

Note: The established themes from Question 2 
There was considerable agreement that the six Principles will remain relevant but may need to be redefined in some ways, in part reflecting the responses to Question 1:

Discussant 3

Yes, PRME will still be relevant, and will be in 100 years, unless there is the end of globalisation and the world is different to today.

Other discussants suggested there may be less emphasis on 'business' and 'corporations' and more emphasis given to 'education' generally and other types of organisations:

Discussant 2

I think the headings make sense, are future-proof and will still matter. I note the principles talk about corporations but I think they may need to change to reflect other organisations.......and.....to reflect a shift in de-centering the corporation.

Some discussants commented on particular Principles and suggested they may need to be reworded to place greater emphasis on certain issues, e.g. anti-corruption (Discussant 15). However, one view expressed was that much more is needed than simply refinement or re-wording and pointed to the need for a paradigm shift:

\section{Discussant 5}

I don't think it's about refinement, that would be too little.....In the1980s or even the 1990s the predominant way of thinking about business was shareholder-driven, very neo-liberal thinking, but right now with the [SDGs]...... we need a paradigm shift. [It] is hard to say by 2068 whether we will need a paradigm shift or whether we will already have gone through a couple...I think the institutions are what is stopping us from looking into paradigm shifts sometimes, the bureaucracy.

This reference to 'institutions' also links to a point made by several discussants that consideration of the Principles raises the issue of 'ownership', i.e. which institution(s) will be the main drivers of PRME in 2068 and what might be the possible impact on the Principles:

Discussant 1

PRME might become an independent body, owned by academic institutions. If that was to happen, PRME might change because it refers to management education. This leads to 
questions not just about whether it will exist but also who governs it. This will determine the nature of the Principles. [Emphasis in original]

The above point links to some of the responses to Question 1 and Question 3 (below) and raises the question of the possible status of the UN and the UN Global Compact by 2068.

\section{Table 4}

\begin{tabular}{|l|ll|}
\hline \multicolumn{1}{|c|}{ Question 3 } & \multicolumn{1}{|c|}{ Themes } \\
\hline $\begin{array}{l}\text { Do you feel that PRME will continue to } \\
\text { exist in 2068 and, if it does, would you }\end{array}$ & - & Existence of globalization \\
regard that as a success or a failure? & - $\begin{array}{l}\text { Pragmatic application and } \\
\end{array}$ & $\begin{array}{l}\text { PRME activity } \\
\end{array}$ \\
& - Management \\
& Institutional roles \\
\hline
\end{tabular}

Note: The established themes from Question 3

There were mixed views as to the likelihood, and the merits, of PRME's continued existence and, in turn, whether it would constitute success or failure. The findings link to Sardar's (2010) third rule of Futures studies, i.e. Futures studies are skeptical, and which emphasises a need to question other possibilities and host alternative views in conversations of the Future. For some of the discussants, PRME's existence was inextricably linked to the future of the UN itself:

$\underline{\text { Discussant } 1}$

.....Will we see a shift from multilateralism to unilateralism? This raises questions about the continued ability of the UN...to bring nations together. So, we can't really look at PRME without looking at governance, how it fits within the UN eco-system...

For Discussant 1, PRME's continued existence also necessitates consideration of 'the language of business' and how it may change and referred to the observations of Prof John Elkington, 'the father of the triple bottom line' and whether that concept is now obsolete, leading to the need to reconsider 'the conceptualisation of what it means to be responsible' and an even greater need for a multi-disciplinary approach to addressing, for instance, the SDGs.

For some discussants, there was a clear need for more actions and less discussion, in other words a greater commitment to a pragmatic application of the Principles and a more pro-active 
approach by PRME to raise its profile, particularly in China, reflecting perhaps the urgency associated with the context and responses to Question 1:

Discussant 9

There needs to be more PR to promote, and more exposure and a greater time allocated to PRME .....The world will need it. PRME needs to be much more active in promoting its existence.

Discussant 14

There needs to be more actions rather than discussions related to PRME.

Some discussants, however, did not believe that PRME would still exist, or even should exist:

Discussant 12

PRME will not exist. More actions rather than discussions or it will be too late. [Our] survival will be priority, particularly clean air and water.

\section{Discussant 5}

In its current form, I don't think it ought to exist by 2068 and if it is still existing then, yes, it's a failure. It's already requiring a lot of reform.... If we keep on like this, first of all, it should not survive to 2068...If we reform, and manage to make PRME better, yes, it should still exist for a little bit longer but by 2068 if we are still talking about responsible management education, as if it is not the norm, then we have a problem.

The belief in the need for more actions and reform reflected, for some, a deeper issue about the management of the UN and other 'institutions' and the roles they fulfil which, deliberately or otherwise, blocked rather than facilitated change, illustrated in a response that was actually made to Question 2:

\section{Discussant 5}

There are lots [of blockers]. Governments could be included, the UN itself is a very established institution, with a lot of policies, a lot of bureaucracy, they have their procedures. If you want anything changing in the UN it takes months or even years. 


\section{Table 5}

\begin{tabular}{|c|c|}
\hline Question 4 & Themes \\
\hline $\begin{array}{l}\text { If you think it will exist in 2068, what } \\
\text { do you imagine a PRME model might } \\
\text { look like? If you do not believe it will } \\
\text { exist, what factors do you think might } \\
\text { lead to it ceasing to exist? }\end{array}$ & $\begin{array}{ll}\text { - } & \text { PRME localization } \\
\text { - } & \text { Fees }\end{array}$ \\
\hline
\end{tabular}

Note: The established themes from Question 4

The response to Question 4 in part linked to responses to Questions 1 and 3 and the issue of governance and, for some, the need for reform:

\section{Discussant 1}

As with Q1, I think the model will depend on the governance. It is voluntary at the moment but we need to think about the umbrella organisation. Who is going to govern PRME? At the moment we have a small team in New York and then a sort of hub-and-spoke through Chapters and working groups. I could envisage the model changing so it's a member-led organisation and you 'pay-to-play', so it would not be voluntary and people would invest in it...I think it will be member-led, governed by academics but I think they will need fulltime officers.

The suggestion that the model should become 'member-led' with a more 'bottom-up' and decentralised approach was also made by other discussants:

Discussant 5

The fundamental problem right now is governance. A lot of....key activities organised by PRME is very top-down....[T]here is a concept of a need to control but the very nature of PRME is that it is very stakeholder-driven. The ideas should come from the business schools, the researchers, from within the working groups....so we should reform what is very centralised, top-down decision-making and governance and give more voice to the signatories....Also, currently there is a lack of transparency. What they are doing in the Global Compact....it is really hard to figure out where exactly the group is going or how much support there is from the Global Compact, from the UN organisation, for PRME itself. 
Even if, in principle, this would be a more appropriate and effective model, the specific circumstances of particular countries would need to be considered:

$\underline{\text { Discussant } 4}$

Adapting to the local environment and community is key to the PRME model. If PRME isn't linked to a [key performance indicator] it is harder to have an industry impact. Having said that, supporting the UN objectives is absolutely an opportunity.

This point was further illustrated by reference to China. The needed localisation for China's PRME activities reflects Sardar's (2010) second law of Futures Studies: Future Studies are Mutually Assured Diversity (MAD):

\section{Discussant 3}

Maybe the model should change. There has not been explosive growth in China. PRME needs to be more pro-active. In China, many institutions and people will find it difficult to find the time to be involved in PRME when obviously the priorities have to be the Government's objectives.

One discussant, however, suggested an opposite approach and the merits, perhaps, in universalising rather than localising discussions:

\section{Discussant 6}

The geographical focus should reduce..... and the emphasis should be on topics, themes, rather than geography. Given technology, such a change should be easy to achieve e.g. establish online forums so people can join in... This would help people bring their own voice, particularly students....

Whatever model is adopted, the status quo or not, there was a view that there are likely to be implications in terms of financing, in turn perhaps having an influence on the current arrangements in relation to fees. 


\section{Table 6}

\begin{tabular}{|l|lll|}
\hline \multicolumn{1}{|c|}{ Question 5 } & \multicolumn{1}{|c|}{ Themes } \\
\hline $\begin{array}{l}\text { If you had three questions to ask a } \\
\text { clairvoyant, what would you ask about } \\
\text { a PRME model in 2068? }\end{array}$ & - $\begin{array}{l}\text { Global warming and } \\
\text { environmental issues } \\
\end{array}$ & Political leadership \\
\hline
\end{tabular}

Note: The established themes from Question 5

A very interesting range of questions was given by the discussants, including, for instance, ones relating to medical advances, gender equality and the scale and implications of AI developments, but two particular themes, or concerns, emerged, viz. those relating to the likely nature and environmental impact of global warming and scenarios relating to the nature and effectiveness of political leadership: What will be the impact of global warming? (Discussant 3). How are people looking at sustainability? (Discussant 5). Will we be more respectful of the natural world and other species (Discussant 2)? How will the world look in terms of natural disasters (Discussant 12)? What issues keep leaders awake at night? (Discussant 1). Will we be more co-ordinated in handling world issues? (Discussion 5). Which country will be the world power? (Discussant 15).

It would be surprising, at any time, if the present did not influence the nature of questions and views about the future, even fifty years into the future, and it is possible that the questions posed by the Discussants may be particularly and perhaps disproportionately influenced by current geopolitical developments and recent reports on climate change. However, the concerns underpinning the questions as to the possible irreversibility of current trends may prove quite prescient, particularly perhaps in the case of climate change, or, alternatively, they may prove to be unduly pessimistic. Whatever the future may look like, however, PRME and management educators are positioned to exercise at least some influence.

\subsection{Conclusions}

The Futures exercise to imagine PRME 2068 was a fascinating one and, it is believed, useful. The findings are pertinent and suggest institutional and disciplinary changes to PRME's future activities. The authors believe that 'wicked problems' in Futures studies are aligned with the qualitative research nature and allow findings to generate rather than test a hypothesis (Sandelowski, 1986). Based on the conversations, questions for further research include those relating to: the most effective way of achieving the goals PRME was established to achieve, 
particularly their role in advancing the achievement of the SDGs, and including reviewing the past and likely future effectiveness of existing arrangements given anticipated changes in the world; the appropriateness of the Principles, in particular whether they need to be more 'inclusive' and apply more explicitly across different sectors and organisations; how to ensure, taking into account advances in technology, engagement with the responsible management agenda across all countries and regions and by all groups, not least students, and disciplines; the future of management education and the future of business schools themselves.

There is much potential for further Futures research related to PRME in China, given the nation's global influence in terms of sustainability and economic stability. Specifically, there is potential for further PRME Futures research more extensively to include the 'forgotten voices' of students. A qualitative PRME study would complement the various quantitative reports as referred to on the PRME website.

To answer the questions of the call, as to what will be wise or virtuous for PRME signatories in 2068, the findings of the paper suggest the following questions to be reflected in all decisions: Based on the wicked problems, it is wise to ask the following questions:

- Should the existence of PRME be assessed on the basis of its contribution to resolving the problems (in particular climate change and sustainability) it initially set out to address?

- Could PRME derive legitimacy independent of the United Nations, given possible uncertainty for the existence of the UN itself in 2068 ?

- Could robots replace managers and could they, and humans, be programmed to behave responsibly? If so, what is 'responsible' and 'who guards the guards?'

- Will PRME governance issues be resolved by financial or locational (e.g. localised or non-Chapter) models?

The potential of PRME to act as an agent of change should not be underestimated but there is a need, as there always is and perhaps particularly now, to look forwards and to do whatever can be done not only to overcome current challenges but to use them as a source of inspiration, particularly for students, as alluded to by one discussant: Will individuals have developed their 
own dream - looked beyond the material and developed to a more spiritual level? (Discussant 6). Despite this aspiration, it is worth noting Sardar's (2010) fourth law of Futures Studies, i.e. that they are futureless and that "the real relevance of the discourse lies in the present" (p.184). In this context, it is worth recording that one of the most notable experiences of the exercise was the level of concern expressed by the students and, as 2068 is considered, the question one asked is perhaps one that warrants particular reflection: 'Will the political class have done anything or will it still be arguing? (Discussant 12). 


\section{References}

Amara, R. \& Lipinski, A. J. (1983). Business Planning for an Uncertain Future: Scenarios and Strategies (Vol. 228). New York: Pergamon Press.

Bernard, H. R. (2000). Social Research Methods: Qualitative and Quantitative Approaches. Thousand Oaks, CA: Sage Publications.

Bogdan, R., Biklen, S. K. (1992). Qualitative Research for Education: An Introduction to Theory and Methods. (2nd Ed). Boston: Allyn and Bacon.

Bothwell, E. (September 26, 2018). World University Rankings 2019: results announced.

Retrieved from https://www.timeshighereducation.com/news/world-university-rankings-2019$\underline{\text { results-announced }}$

Cajazeira, J.E.R. (2008). Executive Briefing of ISO 26000 Guidance on Social Responsibility and HKQAA-HSBC CSR Index. Hong Kong Quality Assurance Agency (HKQAA) Symposium, Hong Kong.

Chui, M., Manyik, J. \& Miremadi, M. (2017). The Countries Most (and Least) Likely to be Affected by Automation. Harvard Business Review. Retrieved from https://hbr.org/2017/04/the-countries-most-and-least-likely-to-be-affected-by-automation

Churchman, C.W. (1967). Guest Editorial: Wicked Problems. Management Science, 14 (4), 141 142.

Dey, I. (1993). Qualitative Data Analysis: A User Friendly Guide for Social Scientists. London: Routledge and Kegan Paul. 
Djordevic, A. \& Cotton, D.R.E. (2011). Communicating the Sustainability Message in Higher Education Institutions. International Journal of Sustainability in Higher Education, 12 (4), 381394.

Guba, E. G. \& Lincoln, Y. S. (1981). Effective evaluation: Improving the usefulness of evaluation results through responsive and naturalistic approaches. San Francisco, Calif.: JosseyBass.

Haski-Leventhal, D. (2013). MBA Students Around the World and their Attitude Towards Responsible Management, Second Annual Study.

Retrieved from http://www.unprme.org/resource-docs/MGSMPRMEMBAStudentStudy2013.pdf

Haski-Leventhal, D. \& Concato, J. (2016). The State of CSR and RME in Business Schools and the Attitudes of their Students, Third Bi-Annual Study.

Retrieved from http://www.unprme.org/resource-docs/25MGSMPRMEReport2016.pdf

Haski-Levanthal, D. \& Manefield, S. (2018). The State of CSR and RME in Business Schools: The Students' Voice Forth Biennial Survey 2018. Retrieved from http://www.unprme.org/resourcedocs/PRMESurvey2018FINAL.pdf

IPCC (Inter-governmental Panel on Climate Change). (2018). Global Warming of $1.5^{\circ} \mathrm{C}$ Switzerland: IPCC

Janesick, V. J. (2001). Intuition and creativity: A pas de deux for qualitative researchers. Qualitative Inquiry, 7 (5), 531-540.

Janesick, V. J. (2003). The choreography of qualitative research design: minuets, improvisations, and crystallization. In N. K. Denzin \& Y. S. Lincoln (Eds.), Strategies of qualitative inquiry, 2nd ed. Thousand Oaks, CA: Sage, 46-79.

Mootee, I. (2013). Design Thinking for Strategic Innovation New Jersey: Wiley. 
Mueller, V., Gray, C. \& Kosec, K. (2014). Heat Stress Increases Long-term Human Migration in Rural Pakistan. Nature Climate Change, 4, 182-185. http://doi.org/10.1038/nclimate2103

Nicholls, J., Hair, J. F., Ragland, C. B. \& Schimmel, K. E. (2013). Ethics, Corporate Social Responsibility, and Sustainability Education in AACSB Undergraduate and Graduate Marketing Curricula: A Benchmark Study. Journal of Marketing Education, 35(2), 129-140.

Patton, M. Q. (2002). Qualitative research and evaluation methods. (3rd Ed.) Thousand Oaks, Calif.: Sage Publications.

Parkes, C., Buonon, A. F. \& Howaidy, G. (2017). The Principles for Responsible Management Education (PRME): The first decade - What has been achieved? The next decade - Responsible Management Education's challenge for the Sustainable Development Goals (SDGs) The International Journal of Management Education, 15, 61-65.

Piantanida, M., \& Garman, N. B. (1999). The qualitative dissertation: A guide for students and faculty. London: Sage.

PRME Website (2018a). Six Principles. Retrieved from http://www.unprme.org/about-prme/the-six-principles.php

PRME Website (2018b). Search Participants. Retrieved from http://www.unprme.org/participation/searchparticipants.php?nameparent $=\&$ country $\% 5 \mathrm{~B} \% 5 \mathrm{D}=\mathrm{China} \&$ from $=\&$ to $=\&$ utype $=\&$ search $=$ Search

PRiMEtime Website (2018): PRiMEtime. Retrieved from https://primetime.unprme.org/about/

Ratcliffe, J. (2002). Scenario planning: Strategic interviews and conversations. Foresight, 4 (1), 19-30. 
Ryan, A., Tilbury, D. (2013). Uncharted waters: voyages for Education for Sustainable Development in the higher education curriculum, Curriculum Journal, 24 (2), 272-294.

Rowe, G., Wright, G. (1999). The Delphi technique as a forecasting tool. International Journal of Forecasting, 15 (4), 353-375.

Rowe, G., Wright, G. \& Bolger, F. (1991). Delphi: A re-evaluation of research and theory. Technological Forecasting and Social Change, 39 (3), 235-251.

Sandelowski, M. (1986). The problem of rigor in qualitative research. Advances in Nursing Science, 8 (3), 27-37.

Sandelowski, M. (1995). Focus on Qualitative Methods. Sample Size in Qualitative Research. Research in Nursing and Health, 18, 179-183.

Sardar, Z. (2010). The Namesake: Futures; futures studies; futurology; futuristic; foresightWhat's in a name? Futures, 42 (3), 177-184.

Shindler, J. V. \& Case, R. E. (1996). Apperception and meaning making in the world of qualitative inquiry: An examination of novice qualitative researchers, Annual AERA Meeting. New York: AERA.

Stewart, D., \& Green, B. (2004). The foresight process in practice. Vector Aerospace Chair of Irish Business Studies, Memorial University.

UN Website (2018). Sustainable Development Goals. Retrieved from https://www.un.org/sustainabledevelopment/sustainable-development-goals/

Wersun, A. (2017). Context and the institutionalisation of PRME: The case of the University for the Common Good. The International Journal of Management Education, 15, 249-262. 
Yeung, M.C.S. (2014). How to Make Green Service Delivery Sustainable? International Proceedings of Economics Development and Research, 69, 87-91.

Yeung, M. C. S. (Unpublished Results). Advanced Design Thinking and UNSDG 3 Well-Being New Elements in UNPRME For Wisdom Development. 